\title{
CHARACTERIZATION AND PRODUCTION OPTIMIZATION OF KERATINASE FROM THREE Bacillus STRAINS
}

\author{
Raden Lukas Martindro Satrio Ari WIBOWO'1, Ragil YULIATMO²* \\ ${ }^{1}$ Laboratory of Microbiology and Enzyme, Politeknik ATK Yogyakarta, Special District of Yogyakarta, 55281, Indonesia \\ ${ }^{2}$ Laboratory of Beam House Operation and Tanning, Politeknik ATK Yogyakarta, Special District of Yogyakarta, 55281, \\ Indonesia, ragilyuliatmo@atk.ac.id
}

Received: 12.08 .2020

Accepted: 26.11 .2020

https://doi.org/10.24264/Ifj.20.4.4

\section{CHARACTERIZATION AND PRODUCTION OPTIMIZATION OF KERATINASE FROM THREE BacilluS STRAINS}

ABSTRACT. Indonesia has large coastal areas. The fisheries are good for exploitation. In the previous studies, bacteria producing keratinase were isolated from fish market waste. Keratinase enzyme is able to degrade keratin on the skin. Enzyme activity is influenced by external conditions, such as $\mathrm{pH}$, temperature, and incubation time. The study aimed to investigate the characteristics and the optimal conditions of the keratinase production. The materials used were keratinase from three Bacillus strains: Bacillus thuringensis BRAW_PT, Bacillus aerius BRAW_ PB, and Bacillus subtilis BRAW_PI. The keratinase was investigated by sodium dodecyl sulfate (SDS PAGE) and nondenaturing polyacrylamide gel electrophoresis (Native PAGE). Conditions of the production were optimized by $\mathrm{pH}$, temperature and incubation time on enzyme activity. The molecular weights of all keratinases from Bacillus species were $94.803 \mathrm{kDa}$ and $70.115 \mathrm{kDa}$. The optimum activity of keratinase from B. thuringensis BRAW_PT and B. firmus BRAW_PI was obtained at $\mathrm{pH}$ 8, while keratinase from B. aerius BRAW_PB was optimal at pH 6-8. Keratinase from $B$. thuringensis BRAW_PT has maximum activity at $25^{\circ} \mathrm{C}$, whereas keratinase from $B$. aerius BRAW_PB and $B$. firmus BRAW_PI at $29^{\circ} \mathrm{C}$. All keratinases from Bacillus species are optimal at 90 minutes incubation. Based on the principal component analysis (PCA), $B$. thuringensis BRAW_PT was discriminated from the other enzymes.

KEY WORDS: production optimization, keratinase enzyme, unhairing, fish market waste

CARACTERIZAREA ȘI OPTIMIZAREA PRODUCTIIEI DE KERATINAZĂ DIN TREI TULPINI DE Bacillus

REZUMAT. Indonezia are mari zone de coastă, iar pescăriile pot fi exploatate. În studiile anterioare, s-au izolat bacterii producătoare de keratinază din deșeurile de pe piața de pește. Enzima keratinază este capabilă să degradeze keratina din piele. Activitatea enzimatică este influențată de condiții externe, cum ar fi pH-ul, temperatura și timpul de incubație. Studiul a urmărit să investigheze caracteristicile și condițiile optime de producție a keratinazei. Materialele utilizate au fost keratinaza din trei tulpini Bacillus: Bacillus thuringensis BRAW_ PT, Bacillus aerius BRAW_PB și Bacillus subtilis BRAW_PI. Keratinaza a fost investigată utilizând electroforeza în gel de dodecil sulfat de sodiu poliacrilamidă (SDS PAGE) și cea fără denaturare (Native PAGE). Condițiile de producție au fost optimizate în ceea ce privește $\mathrm{pH}$-ul, temperatura și timpul de incubație pentru activitatea enzimatică. Greutatea moleculară a keratinazelor din speciile Bacillus a fost de 94,803 kDa și 70,155 kDa. Activitatea optimă a keratinazei din B. thuringensis BRAW_PT și B. firmus BRAW_PI a fost obținută la pH 8, în timp ce keratinaza din B. aerius BRAW_PB a fost optimă la pH 6-8. Keratinaza din B. thuringensis BRAW_PT are activitate maximă la $25^{\circ} \mathrm{C}$, iar keratinaza din B. aerius BRAW_PB și B. firmus BRAW_PI la $29^{\circ} \mathrm{C}$. Toate keratinazele din speciile Bacillus sunt optime la 90 de minute de incubație. Pe baza analizei componentei principale (PCA), B. thuringensis BRAW_PT s-a evidențiat din rândul celorlalte enzime.

CUVINTE CHEIE: optimizare producție, enzimă keratinază, îndepărtarea părului, deșeuri de pe piața de pește

\section{CARACTÉRISATION ET OPTIMISATION DE LA PRODUCTION DE KÉRATINASE À PARTIR DE TROIS SOUCHES de Bacillus}

RÉSUMÉ. L'Indonésie a de vastes zones côtières et les pêcheries sont bonnes pour l'exploitation. Dans l'étude précédente, des bactéries produisant de la kératinase ont été isolées des déchets du marché aux poissons. L'enzyme kératinase est capable de dégrader la kératine sur la peau. L'activité enzymatique est influencée par des conditions externes, telles que le $\mathrm{pH}$, la température et la durée d'incubation. L'étude visait à étudier les caractéristiques et les conditions optimales de la production de kératinase. Les matériaux utilisés étaient la kératinase de trois souches de Bacillus : Bacillus thuringensis BRAW_PT, Bacillus aerius BRAW_PB et Bacillus subtilis BRAW_PI. La caractérisation de la kératinase a été étudiée par électrophorèse sur gel de polyacrylamide en présence de dodécylsulfate de sodium (SDS PAGE) et par électrophorèse non dénaturante (Native PAGE). Les conditions de production ont été optimisées par le pH, la température et le temps d'incubation sur l'activité enzymatique. Les poids moléculaires de toutes les kératinases de l'espèce Bacillus étaient de $94.803 \mathrm{kDa}$ et $70.115 \mathrm{kDa}$. L'activité optimale de la kératinase de $B$. thuringensis BRAW_PT et $B$. firmus BRAW_PI a été obtenue à $\mathrm{pH} 8$, tandis que la kératinase de $B$. aerius BRAW_PB a été optimale à $\mathrm{pH}$ 6-8. La kératinase de $B$. thuringensis BRAW_PT a une activité maximale à $25^{\circ} \mathrm{C}$, tandis que la kératinase de $B$. aerius $\mathrm{BRAW} \_\mathrm{PB}$ et $B$. firmus BRAW_PI à $29^{\circ} \mathrm{C}$. Toute la kératinase des espèces de Bacillus est optimale à 90 minutes d'incubation. Sur la base de l'analyse des composants principaux (PCA), B. thuringensis BRAW_PT se démarque des autres enzymes.

MOTS CLÉS : optimisation de la production, enzyme kératinase, épilage, déchets du marché du poisson

\footnotetext{
* Correspondence to: Ragil YULIATMO, Laboratory of Beam House Operation and Tanning, Politeknik ATK Yogyakarta, Special District of Yogyakarta, 55281, Indonesia, ragilyuliatmo@atk.ac.id
} 


\section{INTRODUCTION}

Indonesia is the world's largest archipelagic state with $54,716 \mathrm{~km}$ of coastline, and 17,508 islands (of which 6,000 are inhabited), and the world's fourth most populous nation (247.5 million) [1]. After China, Indonesia is the second largest fish producer in the world, with capture fisheries and aquaculture production. Fish supply in Indonesia has been increasing over the past 50 years, from 0.8 million tons in 1,960 to 10.7 million tons in 2014 [2]. The proportion of the catch is consumed in dried, salted, smoked, boiled or fermented form, while 46 percent is consumed fresh from fish market [1].

In the previous study, Wibowo et al. [3] have isolated the bacteria producing keratinase enzymes from fish market waste. The enzyme is used in the unhairing process for environmentally friendly fish skin tanning. According to Tamersit and Bouhidel [4], unhairing generates heavily polluted solutions. Dettmer et al. [5] also stated that the conventional lime-sulfide in unhairing process leads to the destruction of the hair, causing emissions with high chemical oxygen demand (COD), biological oxygen demand (BOD), and total suspended solid (TSS) loads in the effluent of these industries. Moreover, during this step in leather industry, strong chemicals are used, such as sodium sulphide and lime, which represent approximately $80-90 \%$ of total pollution of leather manufacturing [6]. Keratinase enzyme is important for the environmentallyfriendly tanning process by reducing the usage of sodium sulfide as chemical [7].

Utilization of enzyme in leather making is a promising application. Researchers discovered the keratinolytic enzymes, most of them produced from Bacillus strain, such as Bacillus aerius NSMk2 [8], Bacillus BPKer and BAKer [9], Bacillus cereus and Bacillus polymyxa [10], and Bacillus suptillis [11]. Enzyme production can be influenced by several factors, such as temperature, $\mathrm{pH}$, and incubation time. Optimizing conditions is a crucial aspect of enzyme production [12]. In the current study, we report the characterization and optimization of keratinase from three different Bacillus strains as an innovative solution in supporting the cleaner production of the tannery.

\section{EXPERIMENTAL}

\section{Production of Keratinase Enzyme}

Preparation of Inoculum for Enzyme Production

The materials used in this study were: B. thuringensis BRAW_PT, B. aerius BRAW_PB, and $B$. subtilis BRAW_PI collected from isolation results of a previous study [3]. The fermentation media was: $0.5 \mathrm{~g} / \mathrm{l}$ sodium chloride, 0.3 $\mathrm{g} / \mathrm{l}$ potassium hydrogen phosphate, $0.4 \mathrm{~g} / \mathrm{l}$ potassium dihydrogen phosphate. Stock solution $(1 \mathrm{~g} / 100 \mathrm{ml}$ Yeast extract; $1 \mathrm{~g} / 100 \mathrm{ml}$ Biological peptone; $0,5 \mathrm{~g} / 100 \mathrm{ml} \mathrm{NaCl}$ and $100 \mathrm{ml}$ distilled water), ammonium sulfate, $20 \mathrm{mM}$ Tris $\mathrm{HCl} \mathrm{pH}$ 8, $12 \mathrm{kDa}$ dialysis bag, $1 \mathrm{mM}$ EDTA, $\mathrm{NaHCO}_{3}$, distilled water. One dose of pure culture result isolate was inoculated from agar media into $5 \mathrm{ml}$ preculture medium, then incubated in a shaker at $120 \mathrm{rpm}$ overnight.

\section{Enzyme Production}

The enzyme production was based on the method of Hoq et al. [13]. One and a half milliliters isolate were inoculated into $50 \mathrm{ml}$ liquid medium, then incubated in a shaker at $120 \mathrm{rpm}$ overnight. Enzyme production is characterized by yellowing. Separation of the isolates from extracellular enzyme was performed by centrifuge at $4^{\circ} \mathrm{C}$ and $3500 \mathrm{rpm}$ for 15 minutes. The resulting supernatant was raw enzyme source whose enzyme activity can be measured. The collected enzyme was measured for enzyme activity.

\section{Enzyme Purification}

One liter of fermentation product culture was centrifuged at $10.000 \mathrm{~g}$ for 15 minutes at $4^{\circ} \mathrm{C}$. The formed supernatant was separated from the pellet. The supernatant was an enzyme extract ready to be concentrated. Purification of enzyme by precipitated by $60 \%$ saturation of ammonium sulfate. Saturation was performed using ammonium sulfate [14]. Ammonium sulfate crystals were added slowly while stirring until dissolved. The solution was left for 24 hours at $4^{\circ} \mathrm{C}$, then centrifuged at $10.000 \mathrm{~g}$ for 15 minutes at $4^{\circ} \mathrm{C}$. This step in order to purifying protein by removing other nutrient such as saccharides and minerals [15]. 
Characterization of Eznyme

Determination of Molecular Weight of Protein by Sodium Dodecyl Sulfate Polyacrylamide Gel Electrophoresis (SDS-PAGE)

Materials for SDS-PAGE include 70\% alcohol, sterilized water, acrylamide solution, Tris $\mathrm{HCl}$, SDS, d H2O, TEMED, ammonium persulfate, glacial acetic acid, Coomassie blue, methanol. The buffers were sodium phosphate, glycine$\mathrm{NaOH}$, Tris acetate. The materials used to test keratinase activity were keratin azure, Tris $\mathrm{HCl}$ $\mathrm{pH} 7.5$ and $10 \%$ TCA solution. Protein separation by SDS-PAGE method aims to separate protein in a sample based on molecular weight. The basic principle of SDS-PAGE is protein denaturation by sodium dodecyl sulfate, followed by separating molecules based on molecular weight by electrophoresis method using gel, in this case, polyacrylamide. Identification and analysis of SDS PAGE compared protein band which was previously separated with standard protein [16].

\section{Protease Activity by Native or Nondenaturing PAGE} Polyacrylamide Gel (Native-PAGE)

Native-PAGE was performed by Hiol et al. [17]. Materials for $10 \%$ concentrated NativePAGE were $30 \%$ acrylamide solution; $0.8 \%$ methylenebisacrylamide (Bis); $1.5 \mathrm{M}$ tris $\mathrm{HCl} \mathrm{pH}$ 8.8; 1.0 M. Tris HCl pH 6.8; N, N, N', N', tetramethylethylenediamine (TEMED); 10\% APS (amonium peroxidisulfate); $0.1 \%$ casein; $50 \%$ glycerol; $A$ and $B$ staining solutions; Tefco clear dry; Running buffer (1.5 g tris aminomethane; 7.2 g glycine, and $500 \mathrm{ml}$ distilled water); $70 \mathrm{~mm}$ Advantec filter paper.

\section{Determination of Vmax and $\mathrm{Km}$}

Kinetic parameters of the enzyme were determined by measuring the keratinase activity at different substrate concentrations. Lineweaver - Burk plot was drawn to determine the values of $\mathrm{Km}$ and $\mathrm{Vmax}$ of the enzyme [18].

\section{Optimization of Enzyme Production}

\section{Keratinase Activity}

Keratinase activity test was performed using keratin azure (Sigma-Aldrich, St. Louis, USA) as keratin substrate from wool and given azo stain. Keratinase activity test was performed based on Wang et al. [19]. Five hundred micro litres enzyme sample was incubated in $5 \mathrm{mg}$ keratin azure solution in $500 \mu \mathrm{L} 50 \mathrm{mM}$ sodium phosphate buffer for 30 minutes at $30^{\circ} \mathrm{C}$ with constant agitation $180 \mathrm{rpm}$ using shaker incubator. Enzyme reaction was stopped by adding $1 \mathrm{ml}$ 10\% TCA solution. The solution was put in ice for 30 minutes, then centrifuged at $13.000 \mathrm{~g}$ for 5 minutes. The absorption of azo stain which was removed in supernatant was measured with $595 \mathrm{~nm}$ wavelength and compared with control tube. The control tube was given the same treatment except enzyme sample was replaced with sodium phosphate buffer.

The Effects of $\mathrm{pH}$, Temperature, and Incubation Time on Keratinase Activity

Keratinase activity in purified enzyme was measured at $\mathrm{pH} 6 ; 7 ; 8 ; 9$; and 10 using the

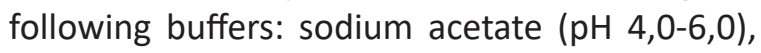
sodium phosphate $(\mathrm{pH} 7,0-8,0)$, and Tris $\mathrm{NaOH}$ buffer ( $\mathrm{pH}$ 9.0-10.0). The optimum temperature was determined by incubation reaction combination at different temperatures, i.e. 25, $27,29,31$ and $33^{\circ} \mathrm{C}$. Beside temperature and $\mathrm{pH}$, incubation time for keratinase characteristic was optimized for 30; 60; 90; 120 and 150 minutes [20].

\section{Data Analysis}

The results obtained from the production optimization were analyzed by analysis of variance (ANOVA) using IBM SPSS Statistics 25. Correlations among the variables were analyzed by Principal Component Analysis (PCA) using Minitab 18 Statistical Software.

\section{RESULTS AND DISCUSSIONS}

\section{Characterization of Keratinase}

SDS PAGE

B. thuringensis strain BRAW_PT, B. aerius BRAW_PB, and $B$. firmus strain BRAW_PI had similar molecular weights of enzyme between $72 \mathrm{kDa}$ and $95 \mathrm{kDa}$. Electrophoresis method was used broadly in protein characterization, including determining molecular weight of 
protein. The molecular weight of enzyme can be measured by calculating the molecular weight of protein which is electrophoresed by polyacrylamide sodium dodecyl sulfate (SDSPAGE) gel and comparing it with molecular weight of standard protein. Bacteria from the genus Bacillus, generally secrete two types of extracellular peptidase, an alkaline peptidase and a neutral peptidase $[19,20]$. This is in accordance with the results obtained by Mazotto et al. [21] Generally, all Bacillus spp. genus had keratinases with molecular weights between 13.8 and $140 \mathrm{kDa}$. The molecular weights of keratinase of the three isolates are presented in Figure 1. The keratinases were detected on various species of Bacillus spp. With molecular weight of 45 to $80 \mathrm{kDa}$ on $B$. subtilis 1270,15 to $100 \mathrm{kDa}$ on $B$. subtilis 1273 , and 63 to $140 \mathrm{kda}$ on B. licheniformis 1274 [22]. Other extracellular keratinases such as on $B$. subtilis ks-1, B. pumilus, and $B$. cereus had molecules with masses of 25.4 , 65 , and $45 \mathrm{kDa}[21,23]$.

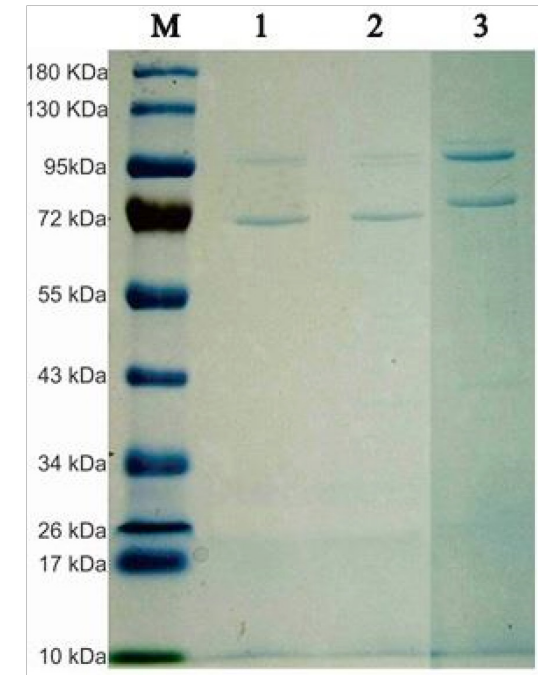

Figure 1. Molecular weight of keratinase from $B$. thuringensis BRAW_PT (1), B. aerius BRAW_PB (2), and $B$. subtilis BRAW_PI (3)

\section{Native-PAGE}

Native-PAGE analysis using casein substrate (Figure 2) demonstrated that the enzymatic extract obtained from three Bacillus strains was able to hydrolyze protein. Protein band of $B$. thuringensis BRAW_PT was very clear, followed by $B$. aerius BRAW_PB, while $B$. firmus BRAW_PI showed thin band. Native-PAGE method was used to determine protein bands, in this case protease activity of certain bacteria. Sattayasai [24] state that many proteins can be stained in gel by using their enzyme activity, native-PAGE are compatible with activity stains. Wilson and Walker [25] also stated that the sample in Native-PAGE process is not denaturized because it can make bonds in the secondary structure of protein to be destructed.

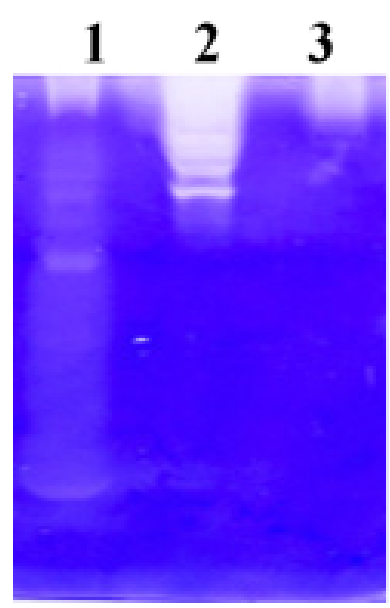

Figure 2. Native-PAGE results of enzyme keratinase from $B$. thuringensis BRAW_PT (1), $B$. aerius BRAW_PB (2), and $B$. firmus BRAW_PI ( 3 )

\section{Kinetics of Keratinase}

The Lineweaver-Burk plot was represented against different concentrations of the substrate with the Michaelis-Menten plot (Fig. 3). The Michaelis constant $(\mathrm{Km})$ of keratinase from $B$. thuringensis BRAW_PT, B. aerius BRAW_PB, and $B$. firmus BRAW_PI were found to be 1.09, 0.46, and $0.10 \mathrm{mg} / \mathrm{ml}$, respectively and the maximum velocity of the reaction (Vmax) were $0.83,7.29$, and $37.4 \mathrm{mg} / \mathrm{ml} / \mathrm{min}$. Kinetic of enzyme was investigated to determine the enzyme reaction rate on different concentrations of the substrate through the Michaelis-Menten equation $(\mathrm{Km})$. Keratinase produced by Pseudomonas aeruginosa KS-1 found higher Km which $1.66 \mathrm{mg} /$ $\mathrm{ml}$ and Vmax which $3.1 \mathrm{mg} / \mathrm{ml} / \mathrm{min}$ [26]. Purified keratinase from $B$. thuringiensis presented higher $\mathrm{Km}(5.97 \mathrm{mg} / \mathrm{ml})$ [27]. The estimated $\mathrm{Km}$ and Vmax values for feather keratin were 6.6 $\mathrm{mg} / \mathrm{ml}$ and $5.0 \mathrm{mg} / \mathrm{ml} / \mathrm{min}$, respectively [28]. 

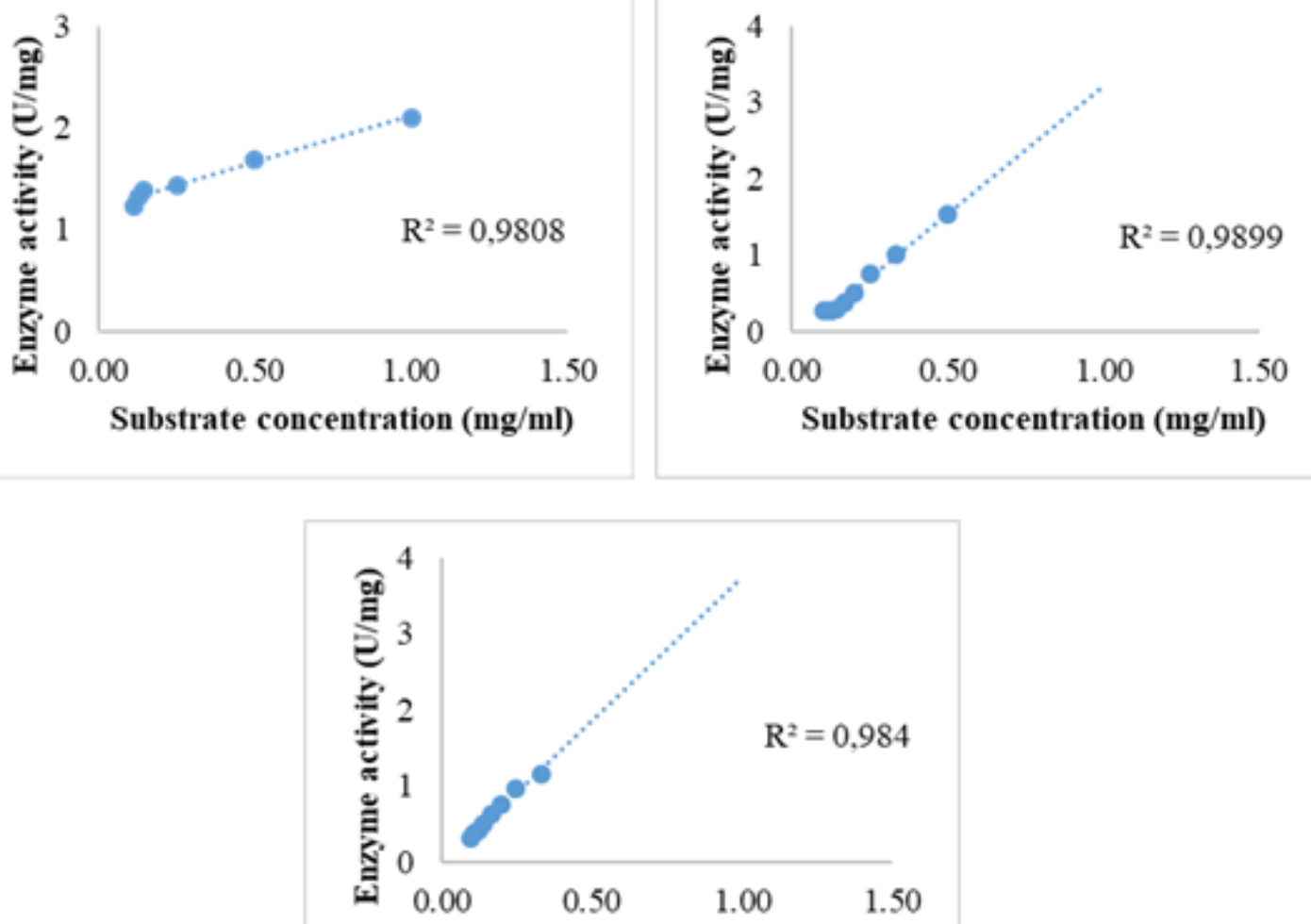

Substrate concentration $(\mathrm{mg} / \mathrm{ml})$

Figure 3. Graph of Line weaver - Burk plot of keratinase

\section{Optimization of Keratinase Production}

The effect of temperature on enzyme activity is depicted in Fig 4. The determination of optimum temperature of keratinase activity was performed by incubating at $25^{\circ} \mathrm{C}-33^{\circ} \mathrm{C}$. Enzyme from $B$. aerius BRAW_PB shows the highest enzyme activity at $29^{\circ} \mathrm{C}(9.39 \pm 0.05 \mathrm{U} / \mathrm{mg})$. Enzyme from $B$. firmus strain BRAW_PI also had optimum activity at $29^{\circ} \mathrm{C}(8.25 \pm 0.10 \mathrm{U} / \mathrm{mg})$. The optimum temperature of enzyme activity from these Bacillus sp stains were almost the same with the results of Balakumar et al. [29]. They state that Bacillus subtilis inoculated in medium and optimized the production at different temperature, and the increased production was identified at $30^{\circ} \mathrm{C}$. However, enzyme from $B$. thuringensis BRAW_PT was optimum at $25^{\circ} \mathrm{C}$, then its activity decreased when the temperature increased. 


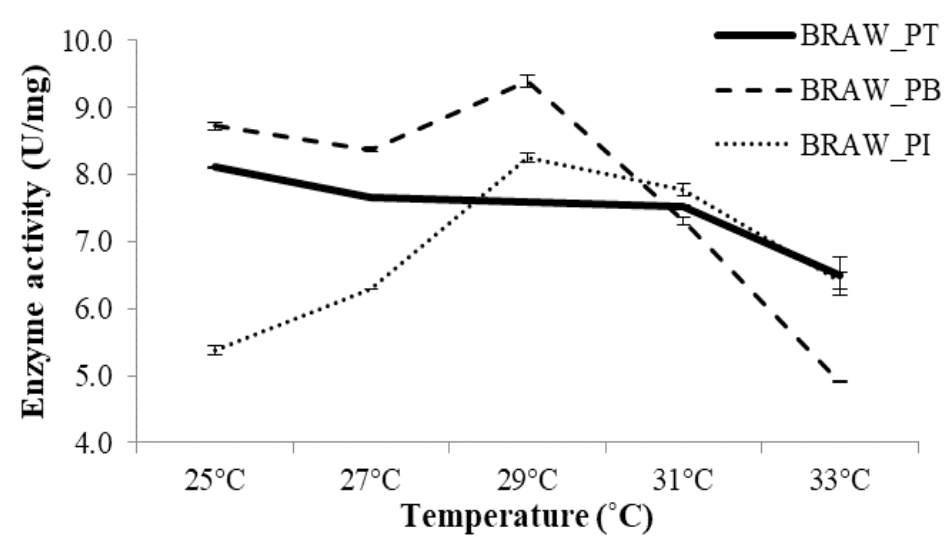

Figure 4. The effect of temperature on keratinase activity

Keratinase from $B$. thuringensis BRAW_PT and $B$. firmus BRAW_PI activities were optimal at $\mathrm{pH} 8$ (Fig 5). However, keratinase activity of B. aerius BRAW_PB was optimal at $\mathrm{pH}$ in the range of 6-8. Selvam et al. [30] indicating that keratinase were produced by Bacillus $\mathrm{sp}$ at $\mathrm{pH}$ between 7 and 8 . Keratinase from these bacteria strains can be categorized as alkaline protease because the optimum activity of the enzyme at alkaline $\mathrm{pH}$. The result was almost similar to alkaline protease from APR-4 Bacillus $\mathrm{sp}$ which has optimum activity at $\mathrm{pH} 9$ [23]. This result of keratinase activity of $B$. aerius BRAW_PB is in accordance with the optimum at $\mathrm{pH} 7.5$ reported previously for azo keratin hydrolysis to hydrolyze fur with keratinase $[31,32]$. Keratinases from Meiothermus taiwanensis WR-220 were also active in a broad range, which is between $\mathrm{pH}$ 4-11 [33].

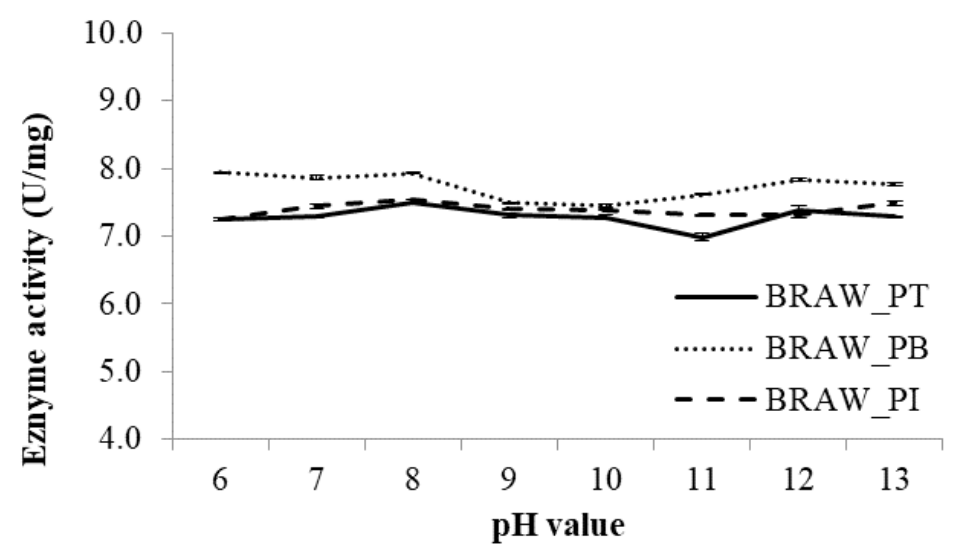

Figure 5. The effect of $\mathrm{pH}$ value on keratinase activity

Activity of all types of enzymes increased for 90 minutes, then it decreased by $9 \%$ after 90 minutes (Fig. 6). The highest activity is that of enzyme from $B$. thuringensis BRAW_PT $(7.72 \pm 0.01 \mathrm{U} / \mathrm{mg})$. Gupta et al. [28] have the same results with the optimum time incubation of keratinase from these bacteria strains, keratinase from $B$. subtilis stabilized up to 90 minutes, and decreased by $11 \%$ after 120 minutes. A different result was found in proteolytic enzyme of $B$. subtilis BLBC 11 [5] and commercial keratinase [34] that had stable activity for 120 minutes. Gessesse et al. [35] reported that enzyme from B. pseudoformis sp. was inactive after 20 minutes, moreover Ogino et al. [36] discovered proteolytic enzyme from Bacillus species that was inactive after only 10 minutes of incubation. 


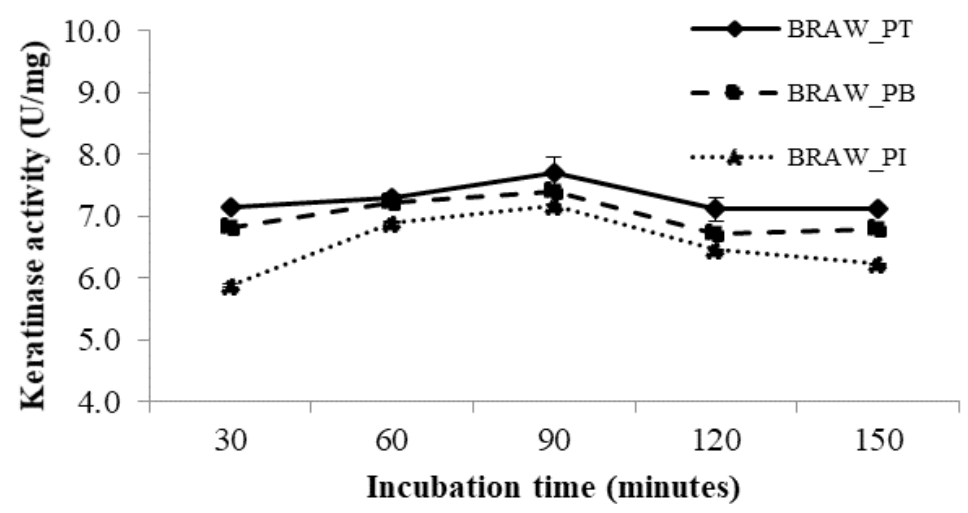

Figure 6. The effect of $\mathrm{pH}$ value on keratinase activity

Correlation among Variables Using Principle Component Analysis

Principal component analysis (PCA) is a statistical analysis method of combining several indexes into a few comprehensive ones. PCA is a calculation method allowing the reduction of variables, correlation among variables, and visualization data [37]. Reducing the amount of variables involves changing the initial set of variables into the new, reduced in number set of the so-called principal components [38]. In addition, the PCA makes the new variables be independent from each other, to achieve the purpose of simplification [39]. The variables that effected the principle component of enzyme activity are shown in Table 1 . Temperature is the most effected to the first principle component
(PC1), while the incubation time is the most effected second principle component (PC2). Table 1 provides the information about that there is a reducing variable, from 3 variables (temperature, $\mathrm{pH}$ value, and incubation time) to 2 variables ( $\mathrm{PC} 1$ and $\mathrm{PC2}$ ). The temperature is the most effected to the first principle component (PC1), while the incubation time is the most effected second principle component (PC2).

Table 1: Correlation between principle components

\begin{tabular}{lll}
\hline Variable & PC1 & PC2 \\
\hline $\mathrm{pH}$ & 0,555 & $-0,660$ \\
Temperature & 0,643 & $-0,045$ \\
Time Incubation & 0,527 & 0,750 \\
\hline
\end{tabular}

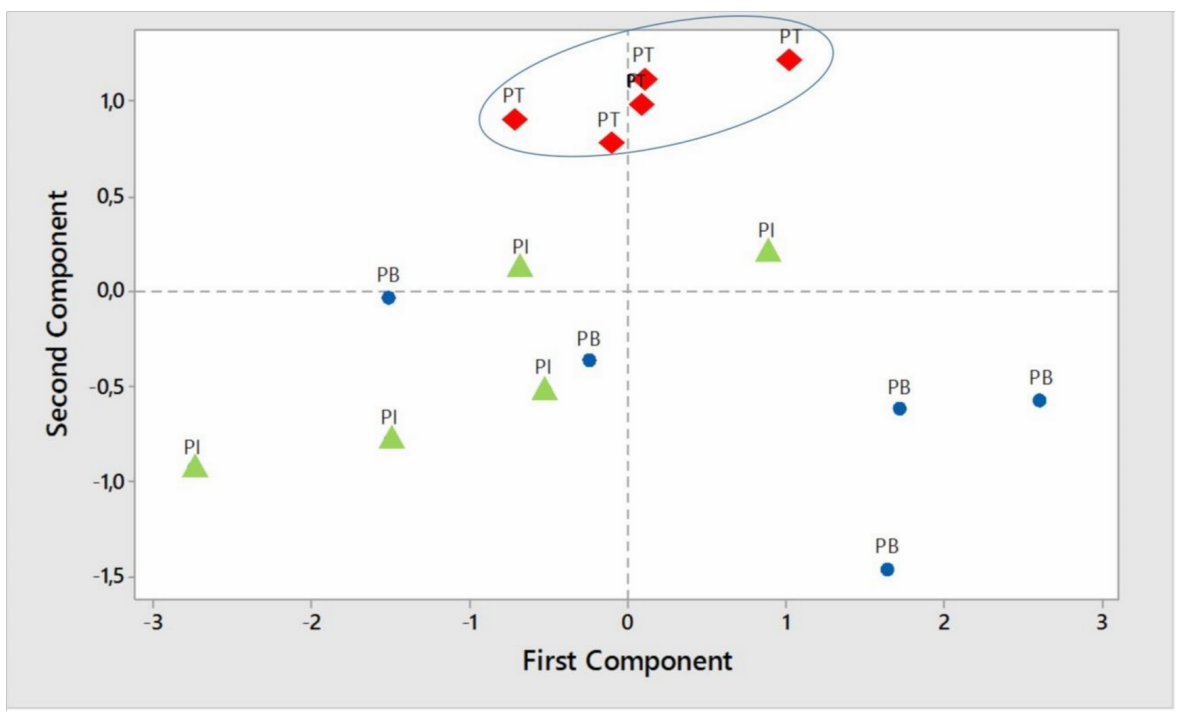

Figure 7. Score plot of type of bacterial producing keratinase strain. PT: Keratinase from $B$. thuringensis BRAW_PT; PB: Keratinase from B. aerius BRAW_PB; PI: Keratinase from B. firmus BRAW_PI 
Moriya et al. [40] used PCA to discriminate the different enzymes. In this study, PCA showed a clear discrimination between keratinase from B. thuringensis BRAW_PT and other enzymes (Fig 6). Figure 7 showed the difference discriminant component of the variables of the bacterial strain. Keratinase from $B$. thuringensis BRAW_PT have a discriminant with other kinds of keratinase (from B. aerius BRAW_PB and B. firmus BRAW_PI).

\section{CONCLUSIONS}

$B$. thuringensis strain BRAW_PT, B. aerius BRAW_PB, and B. firmus strain BRAW_PI had similar molecular weights of enzyme between $72 \mathrm{kDa}$ and $95 \mathrm{kDa}$. Protein band on nativePAGE of $B$. thuringensis BRAW_PT was very clear, followed by $B$. aerius BRAW_PB, while B. firmus BRAW_PI showed thin band. The Michaelis constant $(\mathrm{Km})$ of keratinase from $B$. thuringensis BRAW_PT, $B$. aerius BRAW_PB, and $B$. firmus BRAW_PI were found to be 1.09, 0.46, and $0.10 \mathrm{mg} / \mathrm{ml}$, respectively and the maximum velocity of the reaction (Vmax) were $0.83,7.29$, and $37.4 \mathrm{mg} / \mathrm{ml} / \mathrm{min}$. The optimum activity of keratinase from $B$. thuringensis BRAW_PT and $B$. firmus BRAW_PI was obtained at $\mathrm{pH} 8$, while keratinase from $B$. aerius BRAW PB at $\mathrm{pH}$ 6-8. Keratinase from $B$. thuringensis BRAW_PT has maximum activity at $25^{\circ} \mathrm{C}$, whereas keratinase from $B$. aerius BRAW_PB and $B$. firmus BRAW_PI at $29^{\circ} \mathrm{C}$. All keratinases are optimal at 90 minutes incubation. Keratinase has optimum activity at $29^{\circ} \mathrm{C}, \mathrm{pH} 8$ to 12 , and 90 minutes of incubation time. The Principal Component Analysis (PCA) resulted some correlations among variables, and discriminated B. thuringensis BRAW_PT among other enzymes.

\section{Acknowledgements}

This work has received financial support from research grants from Politeknik ATK Yogyakarta, Ministry of Industry of Republic Indonesia.

\section{REFERENCES}

1. FAO, Fishery and Aquaculture Country Profiles of The Republic of Inonesia, 2019, available at: http://www.fao.org/fishery/facp/IDN/en.
2. Tran, N., Rodriguez, U.P., Chan, C.Y., Phillips, M.J., Mohan, C.V., Henriksson, P.J.G., Koeshendrajana, S., Suri, S., Hall, S., Indonesian aquaculture futures: An analysis of fish supply and demand in Indonesia to 2030 and role of aquaculture using the AsiaFish model, Mar Policy, 2017, 79, May, 25-32, https://doi. org/10.1016/j.marpol.2017.02.002.

3. Wibowo, R.L.M.S., Bachruddin, Z., Fitriyanto, N.A., Nakagawa, T., Hayakawa, T., Pertiwiningrum, A., Screening and Characterization of Keratinolytic Bacteria from Puffer Fish Skin Waste, Pakistan J Nutr, 2017, 16, 488-496, https://doi.org/10.3923/ pjn.2017.488.496.

4. Tamersit, S., Bouhidel, K.E., Treatment of tannery unhairing wastewater using carbon dioxide and zinc cations for greenhouse gas capture, pollution removal and water recycling, J. Water Process Eng, 2020, 34, December 2019, 101120, https://doi. org/10.1016/j.jwpe.2019.101120.

5. Dettmer, A., Cavalli, É., Ayub, M.A.Z., Gutterres, M., Environmentally friendly hide unhairing: Enzymatic hide processing for the replacement of sodium sulfide and delimig, J Clean Prod., 2013, 47, 11-18, https://doi. org/10.1016/j.jclepro.2012.04.024.

6. Dettmer, A., Coelho Cavalheiro, J., Cavalli, E., Misturini Rossi, D., De Souza Gusatti, C., Záchia Ayub, M.A., Gutterres, M., Optimization of the Biotechnological Process for Hide Unhairing in Substitution of Toxic Sulfides, Chem Eng Technol, 2012, 35, 5, 803-810, https://doi. org/10.1002/ceat.201100350.

7. Kandasamy, N., Velmurugan, P., Sundarvel, A., Jonnalagadda Raghava, R., Bangaru, C., Palanisamy, T., Eco-benign enzymatic dehairing of goatskins utilizing a protease from a Pseudomonas fluorescens species isolated from fish visceral waste, J Clean Prod, 2012, 25, 27-33, https://doi.org/10.1016/j. jclepro.2011.12.007.

8. Bhari, R., Kaur, M., Singh, R.S., Thermostable and halotolerant keratinase from Bacillus aerius NSMk2 with remarkable dehairing and laundary applications, J Basic Microbiol, 2019, 59, 6, 555-568, https://doi.org/10.1002/ jobm. 201900001. 
9. Gegeckas, A., Šimkutè, A., Gudiukaitè, R., Čitavičius, D.J., Characterization and application of keratinolytic paptidases from Bacillus spp., Int J Biol Macromol, 2018, 113, 2017, 1206-1213, https://doi.org/10.1016/j. ijbiomac.2018.03.046.

10. Laba, W., Rodziewicz, A., Biodegradation of hard keratins by two Bacillus strains, Jundishapur J Microbiol, 2014, 7, 2, 1-7, https://doi.org/10.5812/jjm.8896.

11. Mousavi, S., Salouti, M., Shapoury, R., Heidari, Z., Optimization of keratinase production for feather degradation by Bacillus subtilis, Jundishapur J Microbiol, 2013, 6, 8, 6-10, https://doi.org/10.5812/jjm.7160.

12. Mechri, S., Kriaa, M., Ben, M., Berrouina, E., Benmrad, M.O., Jaouadi, N.Z., Rekik, H., Bouacem, K., Bouanane-darenfed, A., Chebbi, A., Sayadi, S., Chamkha, M., Bejar, S., Jaouadi, B., Optimized production and characterization of a detergent-stable protease from Lysinibacillus fusiformis C250R, Int I Biol Macromol, 2017, 101, 383-397, https://doi. org/10.1016/j.ijbiomac.2017.03.051.

13. Hoq, M.M., Siddiquee, K.A.Z., Kawasaki, H., Seki, T., Keratinolytic activity of some newly isolated Bacillus species, Journal of Biological Sciences, 2005, 193-200, https:// doi.org/10.3923/jbs.2005.193.200.

14. Tatineni, R., Doddapaneni, K.K., Potumarthi, R.C., Vellanki, R.N., Kandathil, M.T., Kolli, N., Mangamoori, L.N., Purification and characterization of an alkaline keratinase from Streptomyces sp., Bioresour Technol, 2008, 99, 1596-1602, https://doi.org/10.1016/j. biortech.2007.04.019.

15. Yuliatmo, R., Fitriyanto, N.A., Bachruddin, Z., Erwanto, Y., Increasing of angiotensin converting enzyme inhibitory derived from Indonesian native chicken leg protein using Bacillus cereus protease enzyme, Int Food Res J, 2017, 24, 4, 1799-1804.

16. Laemmli, U.K., Cleavage of Structural Proteins during the Assembly of the Head of Bacteriophage T4, Nature, 1970, 227, 5259, 680-685, https://doi.org/10.1038/227680a0.

17. Hiol, A., Jonzo, M.D., Druet, D., Comeau, L., Production, purification and characterization of an extracellular lipase from Mucor hiemalis f. hiemalis, Enzyme Microb Technol, 1999, 25, 80-87, https://doi.org/10.1016/S01410229(99)00009-5.

18. Park, C.H., Lee, S.J., Lee, S.G., Lee, W.S., Byun, S.M., Hetero- and autoprocessing of the extracellular metalloprotease (Mpr) in Bacillus subtilis, J Bacteriol, 2004, 186, 19, 6457-6464, https://doi.org/10.1128/ JB.186.19.6457-6464.2004.

19. Wang, R.U.I., Min, C., Haiming, C., Li, Z., Enzyme Unhairing - An Eco-Friendly Biotechnological Process, I Soc Leath Tech Ch, 2009, 93, 2, 51-55.

20. Tang, X.M., Lakay, F.M., Shen, W., Shao, W.L., Fang, H.Y., Prior, B.A., Wang, Z.X., Zhuge, J., Purification and characterisation of an alkaline protease used in tannery industry from Bacillus licheniformis, Biotechnol Lett, 2004, 26, 18, 1421-1424, https://doi. org/10.1023/B:BILE.0000045642.19299.3f.

21. Mazotto, A.M., Coelho, R.R.R., Cedrola, S.M.L., De Lima, M.F., Couri, S., Paraguai De Souza, E., Vermelho, A.B., Keratinase production by three Bacillus spp. using feather meal and whole feather as substrate in a submerged fermentation, Enzyme Res., 2011, 2011, 1, https://doi.org/10.4061/2011/523780.

22. Mazotto, A.M., de Melo, A.C.N., Macrae, A., Rosado, A.S., Peixoto, R., Cedrola, S.M.L., Couri, S., Zingali, R.B., Villa, A.L.V., Rabinovitch, L., Chaves, J.Q., Vermelho, A.B., Biodegradation of feather waste by extracellular keratinases and gelatinases from Bacillus spp., World J Microbiol Biotechnol, 2011, 27, 6, 1355-1365, https://doi.org/10.1007/s11274-010-0586-1.

23. Kumar, A.G., Swarnalatha, S., Gayathri, S., Nagesh, N., Sekaran, G., Characterization of an alkaline active - Thiol forming extracellular serine keratinase by the newly isolated Bacillus pumilus, J Appl Microbiol, 2008, 104, 2, 411-419, https://doi.org/10.1111/j.13652672.2007.03564.x.

24. Sattayasai, N., Protein Purification, in Deniz Ekinci (ed.), Chemical Biology, IntechOpen, 2012, available at: http://www.intechopen. com/books/chemical-biology/proteinpurification, https://doi.org/10.5772/35425.

25. Wilson, K., Walker, J., Principles and Techniques of Practical Biochemistry, 
Cambridge, UK: Cambridge University Press, 2010.

26. Sharma, R., Gupta, R., Substrate specificity characterization of a thermostable keratinase from Pseudomonas aeruginosa KS-1, 2010, 785-792, https://doi.org/10.1007/s10295010-0723-8.

27. Sivakumar, T., Shankar, T., Ramasubramanian, V., Purification Properties of Bacillus thuringiensis TS2 Keratinase Enzyme, 2012, 12, 12, 1553-1557, https://doi.org/10.5829/ idosi.aejaes.2012.12.12.1905.

28. Gupta, S., Nigam, A., Singh, R., Purification and characterization of a Bacillus subtilis keratinase and its prospective application in feed industry, Acta Biol Szeged, 2015, 59, 2, 197-204.

29. Balakumar, S., Mahesh, N., Arunkumar, M., Sivakumar, R., Hemambujavalli, V., Optimization of keratinase production by Keratinolytic organisms under submerged fermentation, Int J PharmTech Res, 2013, 5, 3, 1294-1300.

30. Selvam, K., Vishnupriya, B., Yamuna, M., Isolation and description of keratinase producing marine actinobacteria from South Indian Coastal Region, African J Biotechnol, 2013, 12, 1, 19-26, https://doi.org/10.5897/ AJB12.2428.

31. Lin, X., Shih, J.C.H., Swaisgood, H.E., Hydrolysis of feather keratin by immobilized keratinase, Appl Environ Microbiol, 1996, 62, 11, 4273-4275, https://doi.org/10.1128/ AEM.62.11.4273-4275.1996.

32. Lin, X., Lee, C.G., Casale, E.S., Shih, J.C.H., Purification andcharacterization of a keratinase from a feather-degrading Bacillus licheniformis strain, Appl Environ Microbiol, 1992, 58, 3271-5.

33. Wu, W.L., Chen, M.Y., Tu, I.F., Lin, Y.C., Eswarkumar, N., Chen, M.Y., Ho, M.C., Wu, S.H., The discovery of novel heat-stable keratinases from Meiothermus taiwanensis WR-220 and other extremophiles, Sci Rep, 2017, 7, 1, 1-12, https://doi.org/10.1038/ s41598-017-04723-4.

34. Dettmer, A., Ayub, M.A.Z., Gutterres, M., Hide unhairing and characterization of commercial enzymes used in leather manufacture, Brazilian J Chem Eng, 2011, 28, 3, 373-380, https://doi.org/10.1590/S010466322011000300003.

35. Gessesse, A., Hatti-Kaul, R., Gashe, B.A., Mattiasson, B., Novel alkaline proteases from alkaliphilic bacteria grown on chicken feather, Enzyme Microb Technol, 2003, 32, 5, 519-524, https://doi.org/10.1016/S01410229(02)00324-1.

36. Ogino, H., Otsubo, T., Ishikawa, H., Screening, purification, and characterization of a leatherdegrading protease, Biochem Eng J, 2008, 38, 2, 234-240, https://doi.org/10.1016/j. bej.2007.07.008.

37. Brereton, R.G., Chemometrics for Pattern Recognition, 2009, John Wiley \& Sons, Ltd, https://doi.org/10.1002/9780470746462.

38. Łojewski, M., Muszyńska, B., Smalec, A., Reczyński, W., Opoka, W., Sułkowska-Ziaja, K., Development of Optimal Medium Content for Bioelements Accumulation in Bacopa monnieri (L.) In Vitro Culture, Appl Biochem Biotechnol, 2014, 174, 4, 1535-1547, https:// doi.org/10.1007/s12010-014-1095-8.

39. Zhang, W.Y., Yao, D.X., Zhang, Z.G., Yang, Q., Zhao, K., An, S.K., Characteristics of soil enzymes and the dominant species of repair trees in the reclamation of coal mine area, $J$ Coal Sci Eng, 2013, 19, 2, 256-261, https:// doi.org/10.1007/s12404-013-0223-3.

40. Moriya, R.Y., Gonçalves, A.R., Faria, F.P., Enzymatic bleaching of organosolv sugarcane bagasse pulps with recombinant xylanase of the fungus Humicola grisea and with commercial cartazyme HS xylanase, Appl Biochem Biotechnol, 2005, 121, 195-203, https://doi.org/10.1385/ABAB:121:1-3:0195.

(C) 2020 by the author(s). Published by INCDTPICPI, Bucharest, RO. This is an open access article distributed under the terms and conditions of the Creative Commons Attribution license (http:// creativecommons.org/licenses/by/4.0/). 